\title{
The Effect of Organizational Communication on Students Learning Motivation at LPK Chakra Dian Utama
}

\section{Vinny Febyola Putri',} Amirul Mukminin²

\section{INSTITUTION}

Program Studi Ilmu Komunikasi,

STIKom Interstudi,

Indonesia

\section{PHONE}

\section{EMAIL}

1febyolav84@gmail.com

ㄹmirul.0104@gmail.com

\section{DOI}

https://www.doi.org/

10.37010/prop.v2i1.585

\section{PAPER PAGE}

$121-134$

PROPAGANDA is a Journal of Communication Studies which is publish twice a year on January and July. PROPAGANDA is a scientific publication media in the form of conceptual paper and field research related to communication studies. It is hoped that PROPAGANDA can become a media for academics and researchers to publish their scientific work and become a reference source for the development of science and knowledge.

\author{
Pengaruh Komunikasi Organisasi terhadap Motivasi \\ Belajar Siswa pada LPK Chakra Dian Utama
}

\begin{abstract}
Komunikasi mempunyai macam-macam jenisnya, salah satunya adalah komunikasi organisasi. Seseorang atau anggota kelembagaan dapat terpengaruh motivasinya melalui komunikasi sebuah organisasi. Di dalam penelitian ini motivasi yang dimaksud adalah motivasi belajar. Tujuan dari penelitian ini adalah seberapa besar atau kuat pengaruh komunikasi organisasi terhadap motivasi belajar peserta didik di LPK Chakra Dian Utama. LPK Chakra Dian Utama adalah Lembaga Pelatihan Kerja (LPK) bahasa Jepang dari tingkat dasar hingga pencapaian level N3 dan melengkapi lembaga dengan semua fasilitas belajar bahasa Jepang yang diperlukan, sesuai dengan persyaratan International. Rancangan dari penelitian ini memiliki tujuan untuk mencari pengaruh antar dua variabel yaitu Variabel (X) adalah Komunikasi Organisasi sedangkan Variabel (Y) adalah Motivasi Belajar. Responden yang dilibatkan dalam penelitian ini adalah peserta didik dan alumni lulusan LPK Chakra Dian Utama yang berjumlah 80 orang. Teknik sampling dalam penelitian ini menggunakan total sampling. Hasil dari penelitian ini menunjukkan bahwa komunikasi organisasi mempunyai pengaruh yang cukup terhadap motivasi belajar peserta didik di LPK Chakra Dian Utama. Koefisien korelasi antara kedua variabel adalah 0,789. Ini menunjukkan bahwa Bauran Komunikasi Organisasi terhadap Motivasi Belajar memiliki hubungan yang cukup karena berada di antara 0,60-0,799. Sedangkan koefisien determinasi adalah sebesar 0,623 yang berarti sebesar $62 \%$ variabel Komunikasi Organisasi mempengaruhi Motivasi Belajar sedangkan sisanya sebesar 38\% dipengaruhi oleh faktor-faktor yang tidak terdapat pada penelitian ini. Hasil akhir dari penelitian ini adalah Komunikasi Organisasi terbukti mempunyai pengaruh sebesar $62 \%$ terhadap Motivasi Belajar.
\end{abstract}

Communication has various types, one of which is organizational communication. A person or institutional member can be influenced by his motivation through the communication of an organization. In this study, the motivation in question is learning motivation. The purpose of this research is how big or strong the influence of organizational communication on the learning motivation of students at LPK Chakra Dian Utama. LPK Chakra Dian Utama is a Japanese Language Job Training Institute (LPK) from basic level to attainment of $N_{3}$ level and equips the institution with all necessary Japanese language learning facilities, in accordance with international requirements. The design of this study aims to find the effect between two variables, namely Variable $(X)$ is Organizational Communication while Variable $(Y)$ is Learning Motivation. Respondents involved in this study were 80 students and alumni of LPK Chakra Dian Utama graduates. The sampling technique in this study uses total sampling. The results of this study indicate that organizational communication has a sufficient influence on the learning motivation of students at LPK Chakra Dian Utama. The correlation coefficient between the two variables is 0.789 . This shows that the Organizational Communication Mix on Learning Motivation has a sufficient relationship because it is between o.6o-0.799. While the coefficient of determination is 0.623 , which means that $62 \%$ of Organizational Communication variables affect Learning Motivation, while the remaining $38 \%$ is influenced by factors not found in this study. The final result of this research is that organizational communication has an effect of $62 \%$ on learning motivation.

\section{KEYWORD}

organizational communication, learning motivation, job training institute komunikasi organisasi, motivasi belajar, lembaga pelatihan kerja 


\section{PROPAGANDA}

\section{PENDAHULUAN}

Manusia adalah makhluk sosial yang setiap harinya sudah pasti melakukan aktivitas yaitu berkomunikasi, komunikasi disebut sebagai proses gagasan, penyampaian informasi, juga pesan-pesan dengan verbal ataupun non verbal melalui satu orang ke orang lainnya atau ke kelompok. Komunikasi juga merupakan nafas pembangunan berkelanjutan suatu organisasi, karena organisasi tidak dapat berfungsi tanpa komunikasi. Seperti yang dikutip oleh Webster, komunikasi sendiri disebut juga sebagai proses bertukarnya informasi melalui perilaku, simbol, ataupun suatu sistem antar individu. Komunikasi dapat disebut juga sebagai proses pertukaran informasi antar organisasi, individu, komunitas yang menciptakan, memanfaatkan dan menggunakan informasi sebagai alat untuk berhubungan dengan lingkungan dan juga orang lain.

Organisasi sendiri terdiri dari banyak orang yang mempunyai masing-masing tugas dan saling terkait satu sama lain yang membutuhkan komunikasi yang sangat baik, agar organisasi dapat berjalan lancar serta tujuan organisasi dapat tercapai. Menurut Mintzberg \& Laasch, (2020) Secara umum organisasi minimal terdiri dari 5 elemen, berikut ; (1) The strategic apex, pimpinan atau manajer puncak yang bertanggung jawab penuh terhadap organisasi; (2) The Operating Core, karyawan yang menjalankan pekerjaan utama terkait dengan barang atau jasa dan segala macam produksi; (3) The Middle Line, manajer yang menghubungkan antar Strategic Apex dan Operating Core; (4) The Techno Structure, semua bagian dalam organisasi yang memiliki tugas melakukan serta melaksanakan standardisasi yang khusus; (5) The staff Support, semua staf yang memberikan layanan untuk mendukung keberlangsungan organisasi. Dituliskan pada Ensiklopedia Administrasi (disusun oleh staf dosen Balai Pembinaan Administrasi Universitas Gadjah Mada) Seorang pemimpin disebut sebagai seseorang yang dalam situasi tertentu melakukan aktivitas agar orang lain terpengaruh melalui komunikasi yang bertujuan agar suatu tujuan atau tugas dapat tercapai. Di lihat dari penjelasan sebelumnya, dapat dikatakan, pemimpin disebut sebagai seseorang dengan kemampuan yang dimiliki untuk dapat mempengaruhi, memotivasi dan mengarahkan anggota organisasi untuk dapat mencapai tujuan pada organisasi melalui komunikasi. Pemimpin melakukan komunikasi tujuannya untuk menyampaikan visi organisasi kepada bawahannya, lalu memotivasi bawahannya untuk dapat berjuang mencapai visi yang telah ditetapkan, membangun sebuah kepercayaan dan nilai dengan tujuan hasil yang efektif dari pencapaian hubungan kerja.

Motivasi yang terbentuk dikarenakan adanya penghargaan ekonomi yang didasari untuk tujuan bersama. Setiap tingkatan baik itu pemimpin ataupun bawahan memiliki rasa tanggung jawab yang sama dalam mencapai sebuah tujuan organisasi atau lembaga. Keputusan yang diambil melalui proses pada kelompok dan masing-masing kelompok untuk dapat terhubung satu sama lain melalui anggota dari beberapa kelompok tersebut. Salah satu penyebab kegagalan suatu organisasi atau lembaga adalah tidak terjalinnya komunikasi yang baik.

Lembaga Pelatihan Kerja atau yang disingkat menjadi LPK, sebagai salah satu bentuk organisasi yang dalam kegiatan operasionalnya dipimpin oleh seorang manajer atau kepala lembaga adalah instansi perorangan atau instansi pemerintah yang badan hukum yang telah memenuhi persyaratan dan memiliki izin untuk menjalankan pelatihan kerja. Menurut (Septyana, 2013:82) Lembaga Pelatihan Kerja adalah Pendidikan nonformal yang dijalankan untuk orang umum yang membutuhkan keterampilan, pengetahuan, bahasa atau sikap yang bertujuan untuk pengembangan diri, profesi, usaha mandiri, melamar pekerjaan, atau mendaftar ke pendidikan yang lebih tinggi. LPK Chakra Dian Utama, adalah salah satu contoh LPK yang berhasil, didirikan pada tanggal 28 Desember 2017 dan sudah memiliki lisensi sejak tanggal 28 Januari 2018 di Bekasi, menyelenggarakan pelatihan khusus bahasa Jepang bagi peserta didik yang dipersiapkan dalam penyaluran tenaga kerja magang di Jepang. LPK Chakra 
Dian Utama memberikan pelatihan bahasa Jepang dari tingkat dasar hingga pencapaian level N3 dan melengkapi lembaga dengan semua fasilitas belajar bahasa Jepang yang diperlukan, sesuai dengan persyaratan International. Layaknya sebuah organisasi, LPK Chakra Dian Utama mempunyai visi yaitu menjadi Lembaga Pengirim terbaik di bidang pengiriman pemagangan tenaga kerja baik domestik maupun di luar negeri. Serta mempunyai misi yaitu membantu Program Pemerintah yang berupaya mengurangi jumlah pengangguran yang ada di Indonesia, memberikan kesempatan kepada putra-putri anak bangsa dalam pengembangan pendidikan, karier, dan usaha. Dalam memberikan pelatihan bahasa Jepang, LPK Chakra Dian Utama juga memberikan motivasi belajar dan pembekalan soft skills kepada peserta didiknya mengenai etos/budaya masyarakat di negara dengan julukan Matahari Terbit tersebut, seperti namun tidak hanya terbatas pada budaya disiplin terhadap waktu, agar seluruh peserta didik dapat mencapai semua tujuan yaitu lulus ujian akhir seleksi magang kerja di Jepang dengan nilai yang baik dan selanjutnya dapat disalurkan untuk memenuhi permintaan tenaga kerja dari Jepang.

Dapat disimpulkan dari uraian tersebut, bahwa setiap peserta didik diperlukan memiliki motivasi belajar yang tinggi, hal ini disebabkan adanya lulusan LPK yang masih memiliki pemahaman belajar yang kurang sehingga lulusan LPK tidak lulus pada tahap wawancara dengan para penerima magang di Indonesia. Masalah yang diangkat dalam penelitian ini adalah, "Apakah komunikasi organisasi berpengaruh pada motivasi belajar peserta didik di LPK Chakra Dian Utama?”. Tujuan dalam penelitian ialah untuk mengukur seberapa besar pengaruh komunikasi organisasi terhadap motivasi belajar peserta didik di LPK Chakra Dian Utama sehingga peserta didik dapat mencapai tujuan mereka berupa magang kerja di Jepang.

Penulis mengharapkan dari hasil riset ini khususnya dalam perkembangan bidang pengetahuan akademis yaitu dapat memberikan perbandingan mengenai teori-teori dari komunikasi kepemimpinan dan motivasi belajar saat penulis pelajari di kelas dan membaca bukunya dengan realita di lapangan. Dan juga penulis mengharapkan hasil penelitian ini di kemudian hari bisa menjadi rujukan bagi penelitian seterusnya.

Manfaat praktis dari hasil riset ini khususnya bagi LPK Chakra Dian Utama sebagai saran dan masukan untuk meningkatkan motivasi belajar bagi peserta didik dengan cara mempererat komunikasi organisasi yang terjalin di LPK Chakra Dian Utama.

Jurnal rujukan penelitian ini merupakan jurnal yang dikutip dari Telkom University yang berjudul Pengaruh Komunikasi Organisasi Terhadap Motivasi Kerja Karyawan Lembaga pengelola Dana Pendidikan. Dengan tinjauan literatur teori komunikasi organisasi dan teori hubungan manusia. Metode penelitian yang dipakai jurnal tersebut adalah kuantitatif dan deskriptif sebagai pendekatan penelitiannya.

Komunikasi Organisasi merupakan proses pertukaran informasi untuk menjalin hubungan timbal balik dalam menghadapi kondisi lingkungan yang tidak menentu, yang disebut komunikasi organisasi. Menurut Wiryanto (2005: 24) komunikasi organisasi disebut sebagai mengirim dan menerima pesan dalam suatu organisasi formal dan informal.

Menurut Goldhaber (1986) bahwa komunikasi organisasi adalah proses dalam menciptakan dan saling menukar pesan di dalam satu jaringan hubungan yang saling bergantung satu sama lain untuk menangani lingkungan yang tidak pasti atau selalu berubahubah. Berdasarkan definisi yang dikemukakan oleh Goldhaber ini mengandung tujuh konsep kunci yaitu: (1) Informasi yang dihasilkan oleh proses komunikasi organisasi terus dipertukarkan tanpa interupsi, karena pada dasarnya merupakan keterbukaan informasi. Proses dan dinamika komunikasi antara sistem dan anggotanya. (2) Informasi, termasuk verbal dan non verbal dalam penyebaran organisasi. (3) Jaringan komunikasi organisasi yang ada pada hakikatnya adalah orang yang menempati suatu tempat dalam organisasi. Mereka membentuk jaringan yang dipengaruhi oleh alamat dan pemrosesan pesan. (4) Sifat organisasi yang terbuka memungkinkan terjadinya situasi yang saling terkait. (5) Hubungan yang ada dalam organisasi membuka pintu sistem kehidupan sosial yang memaksa orang untuk menghubungkan pesan. 


\section{PROPAGANDA}

(6) Lingkungan, meliputi semua faktor sosial dan fisik. (7) Ketidakpastian, terlepas dari apakah terdapat perbedaan antara informasi yang diharapkan.

Tujuan komunikasi organisasi untuk menjalin saling pengertian antar anggota. Menurut (Likert, n.d.) Bentuk organisasi yang memanfaatkan sumber daya manusianya secara maksimal ialah organisasi yang memiliki hubungan erat dengan bawahannya sehingga memiliki hasil kerja yang efektif. Komunikasi organisasi juga memiliki andil besar dalam membangun iklim organisasi yang berdampak pada pembangunan budaya organisasi.

Hubungan manusia menurut Barnard, teori yang menitikberatkan pada pentingnya komunikasi dan hubungan sosial di dalam suatu aktivitas organisasi. Adanya pernyataan teori hubungan manusia yaitu tentang perbaikan dan juga penyempurnaan individu pada organisasi dengan tujuan membentuk organisasi yang dapat mendukung suatu individu untuk dapat mengembangkan kemampuannya dan juga meningkatkan kepuasan terhadap seluruh anggota yang ada di dalam organisasi.

Motivasi adalah proses menghasilkan energi yang dirancang untuk mencapai suatu tujuan yang ingin dicapai. Berdasarkan penelitian Kapur \& Islamia (2015) dan Amstrong, (2009) motivasi dibagi menjadi dua bagian, yaitu motivasi dorongan atau yang timbul dari dalam diri sendiri atau bisa di sebut juga motivasi internal dan motivasi yang muncul dan dorongan karena adanya pengaruh lingkungan sekitar yang disebut motivasi eksternal, sehingga akan mendorong orang dewasa untuk belajar lebih lanjut. Teori lain mengatakan menurut J Winardi (2015) edisi revisi, motivasi berasal dari kata motivation yang memiliki arti "menggerakkan". Hasil dari banyak proses di dalam atau di luar individu, dan proses yang membangkitkan semangat dan ketekunan dalam diri seseorang terhadap kegiatan tertentu disebut motivasi Manusia termotivasi untuk dapat mencapai sebuah tujuan yang didasari kebutuhan manusia itu sendiri. Dengan mengacu pada beberapa komentar dan penjelasan yang telah diuraikan sebelumnya, maka dapat dikatakan bahwa motivasi termasuk dalam pendorong seseorang untuk mencapai tujuannya, salah satu contohnya adalah untuk memotivasi dalam belajar. Kecenderungan untuk berhasil tergantung pada motivasi dan kesempatan serta intensitas, dan sebaliknya kecenderungan akan kegagalan.

Motivasi belajar ialah gerak, arah, dan pengawal dari perilaku seseorang dimotivasi untuk bertindak dan melakukan sesuatu guna mencapai tujuan atau hasil tertentu yang dicapai dengan usahanya. Menurut Sardiman (2012:75) Motivasi sebagai inti dari dorongan internal siswa secara keseluruhan, mendorong kegiatan belajar untuk mencapai tujuan yang diharapkan. Motivasi mempunyai pengaruh yang besar terhadap belajar untuk mencapai tujuan yang diharapkan. Motivasi mempunyai pengaruh yang besar terhadap belajar, karena motivasi belajar merupakan perubahan energi seseorang untuk mencapai suatu tujuan. Peranan motivasi belajar adalah apabila siswa sudah memiliki tingkat motivasi yang tinggi dalam kegiatan belajar, motivasi ini berasal dari motivasi internalnya sendiri, tetapi juga didorong oleh eksternal atau orang lain, maka dapat dikatakan bahwa kegiatan belajar itu proses berhasil. Adapun tanggung jawab yang harus dimiliki dari pendidik dan pimpinan adalah bagaimana caranya menumbuhkan motivasi belajar pada peserta didik. Menurut Sardiman (2012:85) menyatakan bahwa pencapaian prestasi seseorang dan pendorong usaha merupakan salah satu fungsi motivasi. Serta menurut Syah (2008: 157). Fungsi dari motivasi yaitu: (1) Motivasi berfungsi sebagai salah satu pendorong perbuatan seseorang. (2) Motivasi berfungsi sebagai salah satu penggerak perbuatan seseorang.(3) Motivasi berfungsi sebagai salah satu pengarah perbuatan seseorang. Motivasi memiliki hubungan yang erat dengan tujuan. Maka dari itu sebuah motivasi dapat memengaruhi adanya suatu kegiatan yang salah satunya berkaitan dengan belajar, karena motivasi merupakan salah satu pendorong yang dipelajari seseorang agar seseorang dapat mencapai tujuannya.

Peran motivasi sangatlah strategis dalam aktivitas belajar seseorang. Tanpa adanya motivasi, jarang sekali seseorang melakukan aktivitas belajar. Agar peran motivasi semakin 
baik atau optimal. Menurut Djamarah (2011: 152) prinsip motivasi belajar yang harus diketahui itu ada enam, yaitu: (1) sebagai penggerak untuk mendorong kegiatan belajar peserta didik. (2) dalam pembelajaran, motivasi intrinsik dinilai lebih penting daripada motivasi ekstrinsik. (3) Motivasi untuk memuji lebih baik dari pada hukuman. (4) Hubungan Motivasi dengan kebutuhan dalam belajar memiliki hubungan yang sangat erat. (5) Optimisme dalam belajar ditimbulkan oleh motivasi. (6) Motivasi dapat melahirkan relasi dalam belajar, agar motivasi belajar dapat lebih optimal, maka prinsip-prinsipnya harus diketahui. Menurut Uno (2008: 23) ada enam indikator yang dapat mengukur tingginya tingkat motivasi yang dapat diterima oleh seseorang, antara lain: (1) Hasrat dan keinginan untuk berhasil dalam belajar dan dalam kehidupan sehari-hari. (2) Ada kebutuhan dan dorongan dalam kegiatan pembelajaran. (3) memiliki keinginan akan cita-cita dan harapan di masa depan. (4) Pemberian penghargaan atas apa yang telah dicapai dalam belajar. (5) Adanya aktivitas menarik dalam pembelajaran. (6) Adanya lingkungan kelas yang kondusif yang membuat peserta didik dapat melakukan aktivitas belajar dengan baik. Bisa kita simpulkan dari beberapa pendapat para ahli di atas mengenai indikator motivasi belajar adalah lingkungan yang dapat memberikan memotivasi kepada peserta didik, kesiapan peserta didik dalam belajar, dan juga adanya hasrat keinginan peserta didik untuk mencapai keberhasilan.

\section{METODE}

Untuk mengetahui seberapa besar peran komunikasi organisasi dalam mempengaruhi motivasi belajar peserta didik, maka metode penelitian yang digunakan peneliti menggunakan metode kuantitatif dalam pengambilan datanya. Menurut Sugiyono (2018:15) bahwa penyebab aktualisasi dalam penelitian adalah bilangan-bilangan konkret dan menggunakan statistik untuk menganalisis datanya.

Penelitian yang digunakan adalah penelitian eksplanatif, berdasarkan Sugiyono (2013: 04) penelitian eksplanatif adalah penelitian yang menjelaskan kedudukan antar variabelvariabel diteliti serta hubungan antara variabel satu dengan yang lain melalui pengajuan hipotesis yang telah dirumuskan. Maka peneliti menggunakan metode kuantitatif dan eksplanatif dalam penelitian ini untuk mengetahui seberapa dalam/jauh pengaruh komunikasi organisasi terhadap motivasi belajar peserta didik.

Sugiyono (2018:151) berpendapat mengenai skala pengukuran ialah persetujuan yang digunakan sebagai referensi guna menetapkan dan memutuskan panjang pendeknya interval terdapat di dalam alat ukur itu. Maka data kuantitatif akan dihasilkan melalui alat ukur kalau dipakai dalam pengukuran. Pada penelitian ini, penulis menggunakan skala ordinal sebagai skala pengukuran variabel. Skala ordinal dipakai untuk menyusun atau mengurutkan setiap kategori mulai dari peringkat yang paling rendah hingga peringkat paling tinggi.

Kemudian penulis menggunakan skala Likert sebagai skala instrumen di penelitian ini. Sugiyono (2018:152) berpendapat pada skala ini digunakan untuk mengukur perilaku dan pendapat individu atau organisasi terhadap fakta yang terkait dengan warga negara. Dan Arikunto (2006:214) juga berpendapat untuk menjauhi simpangan atau bias dikarenakan adanya kecenderungan bagi responden untuk memutuskan jawaban yang ada di tengah sebagai alternatif, maka dengan menghapuskan pilihan "netral" pada kuesioner dan jawaban responden yang digunakan empat pilihan saja. Maka pilihan jawaban pada instrumen penelitian ini adalah;

$\begin{array}{llll}\text { Sangat Setuju (SS) } & =\text { Skor } 4 & \text { Setuju (S) } & =\text { Skor } 3 \\ \text { Tidak Setuju (TS) } & =\text { Skor } 2 & \text { Sangat Tidak Setuju (STS) } & =\text { Skor } 1\end{array}$




\section{PROPAGANDA}

Bungin \& Sos (2005: 109) menjelaskan bahwa populasi yang terdapat pada penelitian ini adalah semua objek penelitian yang memiliki wujud. Populasi yang akan dikaji oleh peneliti juga memiliki karakteristik dan jumlah khusus, yang dilakukan selanjutnya adalah mengambil konklusi atau simpulannya. Populasi yang digunakan oleh penelitian ini adalah peserta didik aktif dan juga alumni peserta didik di LPK Chakra Dian Utama. Terdapat total 80 orang yang terdiri dari alumni dan peserta didik yang belajar di LPK Chakra Dian Utama.

Bersumber pada Sugiyono (2017) sampel disebut juga sebagai sebagian dari karakter dan spesifik pada suatu populasi. Sampel yang akan digunakan adalah yang benar-benar mewakili populasi tersebut. Sampel juga merupakan bagian dari populasi terjangkau yang memenuhi kriteria penelitian jadi di penelitian ini kriteria sampel yang akan digunakan pada penelitian ini ialah alumni dan peserta didik di LPK Chakra Dian Utama berjumlah 80 siswa.

Teknik pengambilan sampel dalam penelitian ini menggunakan total sampling. Menurut Sugiyono (2017:62) total sampling mengambil jumlah sampel sama dengan total populasi. Jika pada suatu penelitian terdapat populasi kurang dari 100 responden, maka semua populasi tersebut yang akan dijadikan sampel penelitian. Dikarenakan jumlah populasi pada penelitian ini ada 80 orang, maka pada penelitian ini, penulis menggunakan metode total sampling.

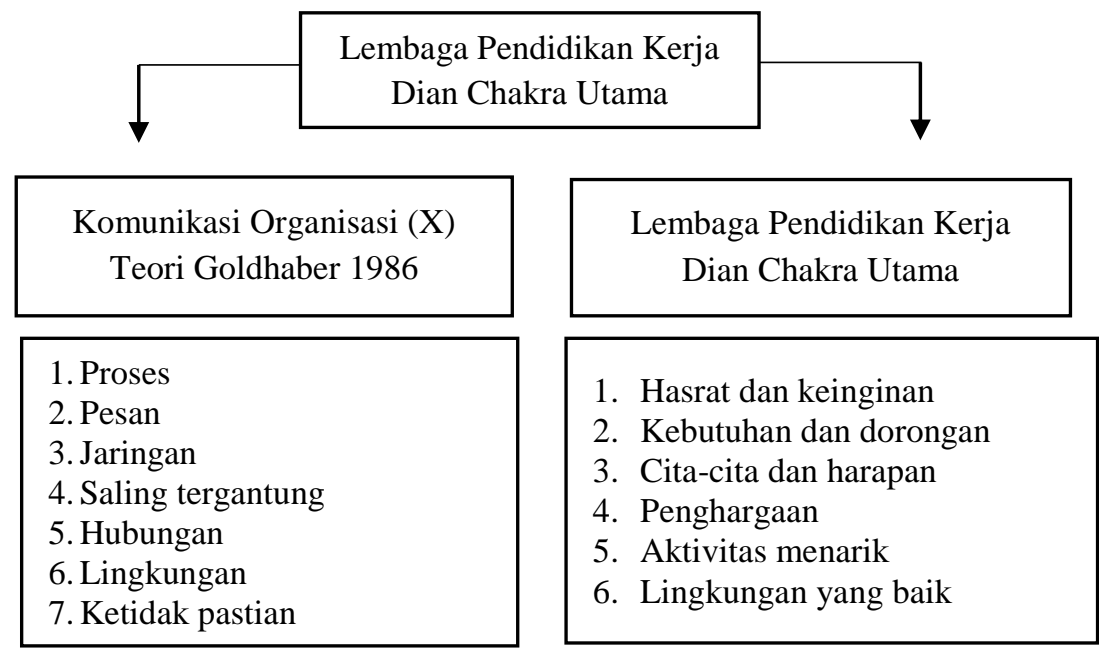

Gambar 1. Kerangka Pemikiran

Menurut (Sugiyono, 2017) uji hipotesis adalah jawaban sementara atas pertanyaanpertanyaan yang terdapat dalam penelitian dan pertanyaan-pertanyaan tersebut dijelaskan dalam bentuk tabel. Dikatakan sementara karena tanggapan yang dihasilkan hanya didasarkan pada teori-teori yang relevan dan tidak hanya pada data empiris yang diperoleh dari hasil pengumpulan data yang disebarkan melalui kuesioner. Berdasarkan teori di atas maka hipotesis penulisan ini adalah:

HO : Tidak terdapat pengaruh antara komunikasi organisasi terhadap motivasi belajar peserta didik LPK Chakra Dian Utama

Ha : Terdapat pengaruh antara komunikasi organisasi terhadap motivasi belajar peserta didik LPK Chakra Dian Utama

Hipotesis statistik merupakan penjelasan tentang keadaan populasi yang sifatnya masih belum pasti kebenarannya. Didasari oleh penelitian yang akan di uji, maka sebagian jawaban sementara atau hipotesis statistiknya adalah sebagai berikut:

Pengujian pengaruh Komunikasi Organisasi (X) kepada Motivasi Belajar (Y).

$\mathrm{H} 0: \beta=0$

Ha $: \beta \neq 0$ Keterangan:

$\mathrm{HO}=$ Hipotesis Nol 
Ha $=$ Hipotesis Alternatif

$\beta=$ Koefisien regresi yang menyatakan pengaruh Komunikasi Organisasi (X) terhadap Motivasi Belajar (Y)

Tabel 1. Interprestasi Koefisien Korelasi

\begin{tabular}{cc}
\hline Koefisien Korelasi & Interprestasi \\
\hline $0,80 \leq \mathrm{rxy} \leq 0,9$ & Korelasi Tinggi \\
$0,70 \leq \mathrm{rxy} \leq 0,80$ & Korelasi Cukup \\
$0,60 \leq \mathrm{rxy} \leq 0,70$ & Korelasi Rendah \\
\hline
\end{tabular}

Uji validitas umumnya digunakan untuk mengukur validitas kuesioner yang ada. Uji validitas merupakan alat untuk mengukur efektivitas penelitian. Jika pertanyaan atau pernyataan dalam angket tersebut, maka angket tersebut dapat dinyatakan valid. (Ghozali, 2016). Cara melakukan uji validitas terdiri dari melihat korelasi antara skor setiap elemen kuesioner dan total skor yang akan diukur. Pada penelitian ini, pengukuran validitas dilakukan dengan cara menggunakan coefficient correlation pearson, dengan menggunakan program SPSS yang digunakan untuk memeriksa uji validitas data dengan menggunakan salah satu rumus. Adapun dasar untuk pengambilan keputusan uji validitas ini dilakukan dengan cara membandingkan nilai rhitung dengan nilai rtabel dengan dua ketentuan sebagai berikut:

a. Jika nilai rhitung > rtabel, maka item pada kuesioner dinyatakan valid.

b. . Jika nilai rhitung < rtabel, maka item pada kuesioner dinyatakan tidak valid.

Alat ukur indikator variabel yaitu kuesioner dapat disebut sebagai uji realibilitas. Reliabel atau tidaknya suatu kuesioner dapat ditentukan jika pernyataan hasil jawaban seseorang stabil dan konsisten (Ghozali, 2016). Pengukuran realibilitas pada penelitian ini dilakukan dengan satu kali injeksi (hanya satu kali pengukuran). Di mana pengukuran terhadap keandalan butir pertanyaan dilakukan dengan menyebarkan kuesioner sekali terhadap responden, dan pertanyaan lain atau mengukur hasil korelasi antara jawaban dengan pertanyaan menggunakan bantuan program SPSS dengan cara melihat nilai Cronbach Alpha hitung dengan ketentuan sebagai berikut:

a. Jika nilai Cronbach Alpha $>0,60$, maka kuesioner dinyatakan reliabel.

b. Jika nilai Cronbach Alpha $<0,60$, maka kuesioner dinyatakan tidak reliabel.

Dalam penelitian ini, peneliti menggunakan teknik analisis regresi sederhana, karena satu variabel bebas akan diasosiasikan dengan satu variabel terikat. Analisis regresi dapat dilakukan melalui variabel independen atau prediktor individu, analisis ini dapat digunakan untuk mengetahui pengaruh variabel terkait dan independen. Menurut Sugiyono (2017) analisis regresi digunakan apabila bagaimana variabel berupa kasual atau fungsional.

Pada variabel independen (X) komunikasi organisasi menurut Goldhaber (1986) terbagi atas tujuh dimensi yakni (1) Proses, (2) Pesan, (3) Jaringan, (4) Keadaan saling tergantung, (5) Hubungan, (6) Lingkungan, (7) Ketidakpastian. Kemudian untuk variabel dependen (Y) motivasi belajar. Menurut (Uno, 2008: 23) ada enam dimensi yang dapat mengukur tingginya tingkat motivasi yang dapat diterima oleh seseorang, antara lain: (1) Hasrat dan keinginan. (2) Kebutuhan dan dorongan. (3) Cita-cita. (4) Penghargaan. (5) Aktivitas. (6) Lingkungan. Pada kedua variabel dan dimensi tersebut dihasilkan indikator dengan jumlah pertanyaan. Berikut tabel 3 Operasional Variabel yang terdiri dari variabel, dimensi, indikator, skala, dan nomor item yang telah dikerjakan penulis dan akan diterangkan. 


\section{Tabel 2. Operasional Konsep}

\begin{tabular}{|c|c|c|c|c|}
\hline Variabel & Dimensi & Indikator & Skala & $\begin{array}{c}\text { No } \\
\text { Item }\end{array}$ \\
\hline \multirow{17}{*}{$\begin{array}{l}\text { Komunikasi } \\
\text { Organisasi (X) } \\
\text { Goldhaber } \\
\text { (1986) }\end{array}$} & \multirow{3}{*}{ Proses } & Pesan yang tercipta secara terus-menerus & Likert & 1 \\
\hline & & $\begin{array}{l}\text { Pertukaran Informasi terjadi secara terus- } \\
\text { menerus }\end{array}$ & Likert & 2 \\
\hline & & $\begin{array}{l}\text { Penyampaian pesan verbal (seperti } \\
\text { percakapan, memo, speech) berlangsung } \\
\text { efektif }\end{array}$ & Likert & 3 \\
\hline & \multirow{3}{*}{ Pesan } & $\begin{array}{l}\text { Penyampaian pesan nonverbal (seperti bahasa } \\
\text { tubuh, mimic wajah, nada bicara) selalu } \\
\text { berlangsung efektif }\end{array}$ & Likert & 4 \\
\hline & & $\begin{array}{l}\text { Penyampaian pesan secara internal } \\
\text { (sosialisasi pekerjaan, rapat) selalu } \\
\text { berlangsung efektif }\end{array}$ & Likert & 5 \\
\hline & & $\begin{array}{l}\text { Penyampaian informasi melalui media } \\
\text { elektronik (seperti email) selalu } \\
\text { berlangsung efektif }\end{array}$ & Likert & 6 \\
\hline & Jaringan & $\begin{array}{l}\text { Jaringan komunikasi antara anggotalembaga } \\
\text { dengan peserta didik berlangsung sesuai jalur } \\
\text { koordinasi }\end{array}$ & Likert & 7 \\
\hline & \multirow{2}{*}{$\begin{array}{l}\text { Keadaan } \\
\text { Saling } \\
\text { Tergantung }\end{array}$} & $\begin{array}{l}\text { Kendala/hambatan yang terjadi di } \\
\text { kelas lain berpengaruh ke kelas lain }\end{array}$ & Likert & 8 \\
\hline & & $\begin{array}{l}\text { Tugas yang dilaksanakan dengankelas lain } \\
\text { selalu berjalan secara lancar }\end{array}$ & Likert & 9 \\
\hline & \multirow[b]{2}{*}{ Hubungan } & $\begin{array}{l}\text { Ikatan/hubungan antar pribadiberlangsung baik } \\
\text { di dalam organisasi/lembaga }\end{array}$ & Likert & 10 \\
\hline & & $\begin{array}{l}\text { Ikatan/hubungan antar siswaberlangsung baik } \\
\text { di dalam organisasi/lembaga }\end{array}$ & Likert & 11 \\
\hline & \multirow[b]{4}{*}{ Lingkungan } & 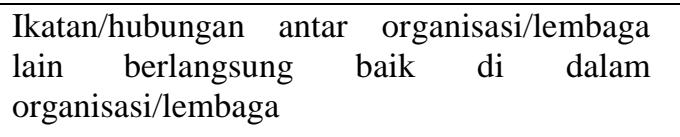 & Likert & 12 \\
\hline & & $\begin{array}{l}\text { Ikatan/hubungan dengan pemerintah } \\
\text { pusat berlangsung baik }\end{array}$ & Likert & 13 \\
\hline & & $\begin{array}{l}\text { Visi dan misi serta fokus organisasi/lembaga } \\
\text { telah diketahui oleh peserta didik }\end{array}$ & Likert & 14 \\
\hline & & $\begin{array}{l}\text { Lingkungan kelas mendukung aktivitas } \\
\text { kegiatan belajar peserta didik }\end{array}$ & Likert & 15 \\
\hline & \multirow[b]{2}{*}{ Ketidakpastian } & $\begin{array}{l}\text { Organisasi/lembaga mencari danmenentukan } \\
\text { informasi/data yang diperlukan }\end{array}$ & Likert & 16 \\
\hline & & $\begin{array}{l}\text { Organisasi/lembaga meriset informasi } \\
\text { regulasi pemerintah pusat terlebih dahulu } \\
\text { sebelum melaksanakan tugasnya }\end{array}$ & Likert & 17 \\
\hline \multirow{5}{*}{$\begin{array}{c}\text { Motivasi } \\
\text { Belajar } \\
(Y) \\
\text { Uno } \\
(2008: 3)\end{array}$} & & Adanya hasrat dan minat belajar & Likert & 18 \\
\hline & $\begin{array}{l}\text { Hasrat dan } \\
\text { Keinginan }\end{array}$ & $\begin{array}{l}\text { Adanya keinginan untuk berhasil dalam } \\
\text { belajar dan dalam kehidupan sehari-hari }\end{array}$ & Likert & 19 \\
\hline & \multirow{2}{*}{$\begin{array}{l}\text { Kebutuhan dan } \\
\text { Dorongan }\end{array}$} & $\begin{array}{l}\text { Adanya kebutuhan tertentu untuk melakukan } \\
\text { kegiatan }\end{array}$ & Likert & 20 \\
\hline & & $\begin{array}{l}\text { Adanya dorongan dari dalam diri untuk } \\
\text { menghindari kegagalan }\end{array}$ & Likert & 21 \\
\hline & & Cita-cita yang tinggi untuk masa depan & Likert & 22 \\
\hline
\end{tabular}




\begin{tabular}{lllc}
$\begin{array}{l}\text { Cita-cita dan } \\
\text { Harapan }\end{array}$ & $\begin{array}{l}\text { Adanya harapan yang didasari oleh keyakinan } \\
\text { diri sendiri untuk berhasil }\end{array}$ & Likert & 23 \\
\hline & $\begin{array}{l}\text { Pemberian penghargaan atas apa } \\
\text { yang telah dicapai dalam belajar }\end{array}$ & Likert & 24 \\
Penghargaan & $\begin{array}{l}\text { Adanya pernyataan verbal seperti } \\
\text { ("hebat"/"bagus") di dalam lembaga atau } \\
\text { penghargaan dalam bentuk lainnya terhadap } \\
\text { perilaku atau hasil belajar yang baik }\end{array}$ & Likert & 25 \\
\hline $\begin{array}{l}\text { Aktifitas } \\
\text { menarik }\end{array}$ & $\begin{array}{l}\text { Adanya kegiatan atau aktifitas menarik selama } \\
\text { kegiatan belajar mengajar yang membuat }\end{array}$ & Likert & 26 \\
\hline $\begin{array}{l}\text { Lemakin bermakna } \\
\text { yang baik }\end{array}$ & $\begin{array}{l}\text { Kenyamanan saat berada di dalam atau luar } \\
\text { kelas Likert }\end{array}$ & 27 \\
\hline
\end{tabular}

\section{HASIL DAN PEMBAHASAN}

Lembaga Pelatihan Kerja adalah Pendidikan nonformal yang dijalankan untuk orang umum yang membutuhkan keterampilan, pengetahuan, bahasa atau sikap yang bertujuan untuk pengembangan diri, profesi, usaha mandiri, melamar pekerjaan, atau mendaftar ke pendidikan yang lebih tinggi. LPK Chakra Dian Utama, adalah salah satu contoh LPK yang berhasil, didirikan pada tanggal 28 Desember 2017 dan sudah memiliki lisensi sejak tanggal 28 Januari 2018 di Bekasi, menyelenggarakan pelatihan khusus bahasa Jepang bagi peserta didik yang dipersiapkan dalam penyaluran tenaga kerja magang di Jepang.

Berdasarkan uraian di atas, peserta didik diharuskan mempunyai motivasi belajar yang sangat tinggi, dikarenakan ada beberapa lulusan di LPK yang kurang memahami pelajaran sehingga mereka tidak lulus pada saat wawancara dengan pihak penerima magang di Jepang. Penelitian ini juga dibuat untuk mengetahui apakah komunikasi organisasi berpengaruh pada motivasi belajar peserta didik.

Maka keinginan penulis adalah mengetahui seberapa besar pengaruh komunikasi organisasi terhadap motivasi belajar peserta didik di LPK Chakra Dian Utama sehingga peserta didik dapat mencapai tujuan mereka berupa magang kerja di Jepang.

Penulis mengharapkan dari hasil riset ini khususnya dalam perkembangan bidang pengetahuan akademis yaitu dapat memberikan perbandingan mengenai teori-teori dari komunikasi organisasi dan motivasi belajar saat penulis pelajari di kelas dan membaca bukunya dengan realita di lapangan. Dan juga penulis mengharapkan hasil penelitian ini di kemudian hari bisa menjadi rujukan bagi penelitian seterusnya. Manfaat praktis dari hasil riset ini khususnya bagi LPK Chakra Dian Utama sebagai saran dan masukan untuk meningkatkan motivasi belajar bagi peserta didik dengan cara mempererat komunikasi organisasi yang terjalin di LPK Chakra Dian Utama. 
Tabel 3. Data Responden

\section{Jenis Kelamin}

\begin{tabular}{ccc|c|c|c}
\multicolumn{2}{c}{ Frequency } & & Percent & Valid Percent & Cumulative Percent \\
\hline \multirow{3}{*}{ Valid } & Laki - Laki & 55 & 68,8 & 68,8 & 68,8 \\
\cline { 2 - 6 } & Perempuan & 25 & 31,3 & 31,3 & 100,0 \\
\cline { 2 - 6 } & Total1 & 80 & 100,0 & 100,0 & \\
\hline
\end{tabular}

Usia

\begin{tabular}{ccc|c|c|c}
\multicolumn{2}{c}{ Frequency } & & Percent 1 & Valid Percent 1 & Cumulative Percent \\
\hline Valid1 & $<18$ Tahun & 4 & 5,0 & 5,0 & 5,0 \\
\cline { 2 - 5 } & $>25$ Tahun & 27 & 33,8 & 33,8 & 38,8 \\
\cline { 2 - 5 } & $19-23$ Tahun & 24 & 30,0 & 30,0 & 68,8 \\
\cline { 2 - 5 } & $23-25$ Tahun & 25 & 31,3 & 31,3 & 100,0 \\
\cline { 2 - 5 } & Total & 80 & 100,0 & 100,0 & \\
\hline
\end{tabular}

\section{Status Belajar}

\begin{tabular}{clc|c|c|c}
\multicolumn{1}{c}{ Frequency } & Percent & Valid Percent & Cumulative Percent \\
\hline Valid & $\begin{array}{c}\text { Alumni/Lulusan LPK Chakra } \\
\text { Dian Utama }\end{array}$ & 59 & 73,8 & 73,8 & 73,8 \\
& $\begin{array}{l}\text { Peserta Didik Aktif LPK Chakra } \\
\text { Dian Utama }\end{array}$ & 21 & 26,3 & 26,3 & 100,0 \\
& \begin{tabular}{l} 
Total \\
\cline { 2 - 5 }
\end{tabular} & 80 & 100,0 & 100,0 & \\
\hline
\end{tabular}

Pada tabel jenis kelamin di atas, hasil penelitian ini adalah jenis perempuan 25 responden dengan persentase $31,3 \%$, sedangkan jenis kelamin laki-laki memperoleh 55 responden dengan persentase $68,8 \%$. Untuk tabel Usia di penelitian ini adalah usia $<18$ Tahun dengan 4 responden dan persentase 5,0\%, sedangkan untuk usia 19-23 Tahun dengan 24 responden dan persentase 30,0\%, sedangkan untuk Usia 23- 25 Tahun dengan 25 responden dan persentase 31,3\%, dan untuk Usia > 25 Tahun dengan 27 responden dan persentase 33,8\%, dan untuk Tabel status dapat dilihat di penelitian ini terdapat alumni/lulusan LPK Chakra Dian Utama sebanyak 59 responden dengan persentase $73,8 \%$ dan peserta didik aktif LPK Chakra Dian Utama dengan responden sebanyak 21 dan persentase $26,3 \%$.

Tabel 4.

\begin{tabular}{clccc}
\hline Variabel & Indikator & R hitung & $\begin{array}{c}\text { R Tabel } \\
(\mathbf{0 , 0 5})\end{array}$ & Keterangan \\
& KO 1 & 0,589 & 0.2199 & Valid \\
& KO 2 & 0,480 & 0.2199 & Valid \\
& KO 3 & 0,595 & 0.2199 & Valid \\
Komunikasi & KO 4 & 0,603 & 0.2199 & Valid \\
Organisasi & KO 5 & 0,685 & 0.2199 & Valid \\
(KO) & KO 6 & 0,395 & 0.2199 & Valid \\
& KO 7 & 0,561 & 0.2199 & Valid \\
& KO 8 & 0,309 & 0.2199 & Valid \\
\hline
\end{tabular}


Vol. 2 No. 1, January 2022

\begin{tabular}{|c|c|c|c|c|}
\hline & KO 10 & 0,601 & 0.2199 & Valid \\
\hline & KO 11 & 0,507 & 0.2199 & Valid \\
\hline & KO 12 & 0,662 & 0.2199 & Valid \\
\hline & KO 13 & 0,645 & 0.2199 & Valid \\
\hline & KO 14 & 0,624 & 0.2199 & Valid \\
\hline & KO 15 & 0,589 & 0.2199 & Valid \\
\hline & KO 16 & 0,566 & 0.2199 & Valid \\
\hline & KO 17 & 0,444 & 0.2199 & Valid \\
\hline \multirow{11}{*}{$\begin{array}{c}\text { Motivasi Belajar } \\
\text { (MB) }\end{array}$} & MB 1 & 0,710 & 0.2199 & Valid \\
\hline & MB 2 & 0,708 & 0.2199 & Valid \\
\hline & MB 3 & 0,609 & 0.2199 & Valid \\
\hline & MB 4 & 0,750 & 0.2199 & Valid \\
\hline & MB 5 & 0,771 & 0.2199 & Valid \\
\hline & MB 6 & 0,680 & 0.2199 & Valid \\
\hline & MB 7 & 0,636 & 0.2199 & Valid \\
\hline & MB 8 & 0,735 & 0.2199 & Valid \\
\hline & MB 9 & 0,710 & 0.2199 & Valid \\
\hline & MB 10 & 0,688 & 0.2199 & Valid \\
\hline & MB 11 & 0,688 & 0.2199 & Valid \\
\hline
\end{tabular}

Berdasarkan hasil pengolahan data yang disajikan tabel di atas, dapat diketahui bahwa semua pertanyaan untuk mengukur variabel independen yaitu Komunikasi Organisasi dan variabel dependen yaitu Motivasi Belajar dinyatakan valid, karena semua pertanyaan menghasilkan rhitung > rtabel.

\section{Tabel 5. Komunikasi Organisasi (KO)}

Reliability Statistics

\begin{tabular}{c|c} 
Cronbach's Alpha & N of Items \\
\hline, 850 & 17 \\
\hline
\end{tabular}

Tabel 6. Motivasi Belajar (MB)

\begin{tabular}{c|c}
\multicolumn{2}{c}{ Reliability Statistics } \\
Cronbach's Alpha & N of Items \\
\hline, 895 & 11 \\
\hline
\end{tabular}

Hasil di atas menunjukkan bahwa kuesioner penelitian reliabel, karena nilai cronbach alpha semua variabel lebih besar dari 0,6. Ini berarti bahwa data yang konsisten dapat diperoleh untuk setiap elemen deklarasi dari semua variabel, yang berarti jika pertanyaan diajukan kembali, jawabannya akan relatif sama dengan yang sebelumnya.

Tabel 7. Model Summary

\begin{tabular}{lllll} 
Model & $\mathrm{R}$ & R Square & Adjusted R Square & $\begin{array}{l}\text { Std. Error of the } \\
\text { Estimate }\end{array}$ \\
\hline 1 &, $789 \mathrm{a}$ &, 623 &, 618 &, 28231 \\
\hline a. Predictors: (Constant), Komunikasi Organisasi
\end{tabular}




\section{PROPAGANDA}

Hasil Analisis Koefisien Korelasi dan Koefisien Determinasi Berdasarkan tabel di atas, diketahui bahwa koefisien korelasi antara variabel Komunikasi Organisasi dan Motivasi Belajar adalah sebesar 0,789.

Tabel di atas dibuat untuk mengetahui nilai hubungan antara variabel bebas (komunikasi organisasi) dan variabel terikat (motivasi belajar). Koefisien korelasi antara kedua variabel adalah 0,789. Ini menunjukkan bahwa Bauran Komunikasi Organisasi terhadap Motivasi Belajar memiliki hubungan yang cukup karena berada di antara 0,60-0,799. Sedangkan koefisien determinasi adalah sebesar 0,623 yang berarti sebesar $62 \%$ variabel Komunikasi Organisasi mempengaruhi Motivasi Belajar sedangkan sisanya sebesar 38\% dipengaruhi oleh faktor-faktor yang tidak terdapat pada penelitian ini. Hasil akhir dari penelitian ini adalah Komunikasi Organisasi terbukti mempunyai pengaruh sebesar 62\% terhadap Motivasi Belajar.

Tabel 8.

\section{Coefficients ${ }^{\mathbf{a}}$}

\begin{tabular}{|c|c|c|c|c|c|c|}
\hline \multirow[t]{2}{*}{ Model } & \multicolumn{3}{|c|}{ Unstandardized Coefficients } & \multirow{2}{*}{$\begin{array}{l}\text { Standardized } \\
\text { Coefficients } \\
\text { Beta }\end{array}$} & $\mathrm{t}$ & \multirow[t]{2}{*}{ Sig } \\
\hline & & B & Std. Error & & & \\
\hline \multirow[t]{2}{*}{1} & (Constant) & 059 & ,308 & & ,193 & 848 \\
\hline & & 1,029 & ,091 & ,789 & 11,345 & ,000 \\
\hline
\end{tabular}

a.Dependent Variable: Motivasi Belajar

Berdasarkan tabel di atas, didapatkan persamaan regresi linear sederhana yang melalui rumus: $\mathrm{Y}=\mathrm{a}+\mathrm{bX}$ di mana:

$\mathrm{X}=$ Komunikasi Organisasi $\mathrm{Y}=$ Motivasi Belajar

$\mathrm{a}=$ Konstanta

$\mathrm{b}=$ Koefisien regresi

Oleh karena itu, mengacu pada rumus tersebut, maka terdapat persamaan linear sederhana: $\mathrm{Y}$ $=0,059+1,029 \mathrm{X}$

Menganalisis hasil perhitungan, dapat dikatakan bahwa nilai a (konstanta) pada tabel unstandarized coefficients (koefisien tidak baku) adalah 0,059 yang artinya jika tidak ada variabel bebas maka nilai variabel motivasi belajar adalah 0,059, dan jika variabel Komunikasi Organisasi sebesar 1, koefisien regresi variabel Motivasi belajar nilainya 1,029. Tingkat signifikasinya adalah 0,000 dan karena $0,000<0,05$ maka dapat dikatakan bahwa pengaruh komunikasi organisasi (variabel X) terhadap motivasi belajar (varibel Y) adalah 5\%. Menurut teori yang digunakan pada penelitian ini, terdapat pengaruh yang signifikan antara Komunikasi Organisasi (X) terhadap Motivasi Belajar (Y), dengan kata lain Komunikasi Organisasi (X) memiliki pengaruh terhadap Motivasi Belajar (Y) menurut data dari alumni dan peserta didik LPK Chakra Dian Utama. Berdasarkan hasil dari penelitian yang telah dilakukan terhadap alumni dan peserta didik LPK Chakra Dian Utama, dapat diketahui bahwa pengaruh dari Komunikasi Organisasi terhadap Motivasi Belajar adalah cukup dan signifikan. Hal ini dapat dilihat dari Uji Analisis Regresi Linear Sederhana yang telah dilakukan pada penelitian ini. Data dari responden kuesioner juga sudah dinyatakan valid dan reliabel. 


\section{PENUTUP}

Berdasarkan penelitian yang telah dilakukan, Dengan uji validitas dan uji reliabilitas dapat diketahui bahwa data survei kuesioner dari 80 responden valid dan reliabel, serta menurut perhitungan uji analisis regresi linear sederhana, dapat diketahui bahwa Komunikasi Organisasi (X) berpengaruh secara signifikan terhadap Motivasi Belajar (Y). Dari uji tersebut juga dapat diketahui bahwa Komunikasi Organisasi (X) memiliki pengaruh yang cukup terhadap Motivasi Belajar (Y).

Saran dari peneliti bagi perusahaan maupun pihak-pihak lain terutama Lembaga Pelatihan Kerja (LPK) Chakra Dian Utama. Pada variabel komunikasi organisasi indikator KO $8(0,309)$ dimensi keadaan saling ketergantungan indikator kendala/hambatan yang terjadi di kelas lain yang berpengaruh ke kelas lain yang mendapatkan $r$ hitung senilai 0,309 yang di mana terendah dibandingkan dengan indikator-indikator lainnya. Saran bagi peneliti untuk Lembaga Pelatihan Kerja (LPK) Chakra Dian Utama adalah Lembaga pelatihan harus menemukan dan memperbaiki setiap hambatan mulai dari para pengajar/instruktur peserta didik, kebutuhan para peserta didik hingga fasilitas-fasilitas yang akan digunakan para peserta didik.

Saran dari peneliti bagi perusahaan maupun pihak-pihak lain terutama Lembaga Pelatihan Kerja (LPK) Chakra Dian Utama. Pada variabel motivasi belajar indikator MB 3 $(0,609)$ dimensi adanya kebutuhan tertentu untuk melakukan kegiatan mendapatkan $r$ hitung 0,609 yang di mana terendah dibandingkan dengan indikator-indikator lainnya. Saran bagi peneliti untuk Lembaga Pelatihan Kerja (LPK) Chakra Dian Utama adalah lembaga pelatihan harus selalu dapat menyediakan kebutuhan para peserta didik saat menjalani kegiatan belajar sehingga para peserta didik tidak terhambat dalam proses pelatihan/pembelajaran

\section{DAFTAR PUSTAKA}

Amstrong, M. (2009). Armstrong's handbook of human resource management practice.

Balai Pembinaan Administrasi Universitas Gadjah Mada. (2021) Kamus Administrasi. Yogyakarta: Universitas Gadjah Mada.

Bungin, P. D. H. M. B., \& Sos, S. (2005). Metodologi Penelitian Kuantitatif: Edisi Kedua. Kencana.

Congge, U. (2015). Potret Birokrat Lokal (Vol. 1). SAH MEDIA.

Ghozali, I. (2016). Aplikasi analisis Multivariete dengan program IBM SPSS 23 (edisi 8). Cetakan ke VIII. Semarang: Badan Penerbit Universitas Diponegoro, 96.

Griffin, R. W., Welsh, A., \& Moorhead, G. (2013). Perceived task characteristics and employee performance: A literature review. Academy of management Review, 6 .

Hasibuan, D. H. M. S. P. (2010). Manajemen Sumber Daya Manusia. Bumi Aksara.

J Winardi, S. E. (2015). Manajemen perilaku organisasi. Prenada Media.

Kapur, S., \& Islamia, J. M. (2015). Indian Journal of Adult Education Indian Adult Education Association. April. https://www.researchgate.net/public ation/281373854

Kogan Page.

Likert, R. (n.d.). Organisasi manusia. Terjemahan Oleh P. Suratno.

McShane, S. \& V. G. (2018). Organizational Behavior 8th Edition. https://www.mheducation.com/highered/product/organizational-behavior-mcshanevon- glinow/M9781259562792.html

Mintzberg, H., \& Laasch, O. (2020). Mintzberg on (ir) responsible management. In Research Handbook of Responsible Management. Edward Elgar Publishing.

n.n. (2017). Komunikasi dalam perspektif teori dan praktik. Yogyakarta: Deepublish. 


\section{PROPAGANDA}

Riswandi. (2009). Ilmu komunikasi. Graha Ilmu. https://books.google.co.id/books?id= mkShAQAACAAJ

Robbins, P. S., \& Coulter, M. (2010). Manajemen, diterjemahkan oleh Bob Sabran, Wibi Hardani. Jakarta: Erlangga.

Sardiman, A. M. (2012). Interaksi \& Motivasi Belajar Mengajar/Sardiman. AM-Ed.

Septyana, H. (2013). Manajemen Pembelajaran Berbasis Kompetensi Pelatihan Menjahit Di Lembaga Pelatihan Kerja Swasta (Lpks) Fortuna Dukuh Siberuk Desa Siberuk Kabupaten Batang. Journal of Non Formal Education and Community Empowerment, 2(2), 46-50.

Sugiyono. (2017). Metode penelitian kuantitatif dan kualitatif dan R\&D. Alfabeta Bandung.

Webster, N. (n.d.). Webster's new collegiate dictionary. 